\title{
Molecular Docking of Compounds in the Essential Oil of Ocimum gratissimum Leaf against PIM-1 Kinase of Escherichia coli
}

\author{
Ijeoma Akunna Duru and Chidi Edbert Duru
}

\section{ABSTRACT}

The activity of the phytochemical compounds in the essential oil of Ocimum gratissimum against PIM-1 kinase of Escherichia coli was studied using computer simulation. The essential oil was extracted by hydrodistillation, and the components identified using a gas chromatography-flame ionization detector (GC-FID) instrument. The quantity of the compounds in the essential oil was in the order isobornyl acetate $(64.3 \%)>$ Octamethylhexadecan-1-ol $(12.2 \%)>$ nonadecanal $(11.5 \%)>$ decanal $(8.7 \%)>$ undecanal $(2.8 \%)>\alpha$-selinene $(0.5 \%)>$ drimenin $(<$ $0.1 \%)$. The results from the in silico studies showed that $\alpha$-selinene had good binding affinity on the PIM-1 kinase target and therefore, could be a promising drug candidate for prostate cancer.

Keywords: $\alpha$-selinene, Essential oil, Hydrodistillation, PIM-1 kinase, Prostate cancer.

\section{INTRODUCTION}

The genus Ocimum L. consists of more than 150 species used in folk medicine and as a source of essential oils in the industry [1], [2]. The species Ocimum gratissimum Lamiaceae is herbaceous plant which belongs to the Labiatae family. It is indigenous to tropical areas, especially India and West Africa. In Nigeria, it is found in the Savannah and coastal areas. It is known by various names in different parts of the world [3]. In India, it has several vernacular names, like Vriddhutulsi (Sanskrit), Ram tulsi (Hindi), Nimma tulasi (Kannada). In Nigeria, the plant is called "Nchanwu" by the Igbos, "efinrin-nla" by the Yorubas, and "Dadoya" by the Hausas [4].

The leaves of $O$. gratissimum have a unique fragrance due to essential oils [5], [6]. Essential oils are compounds found in plants with different properties related to their survival and defense [7]. However, the chemical composition of these oils varies according to the genotype of the plant, geographical origin, environmental conditions, the season of the year, method of extraction of this oil, and its preservation [8]. Many chemicals have been reported to be present in the essential oil of $O$. gratissimum, such as thymol, eugenol, geraniol, $\beta$-caryophyllene, $\gamma$-terpinene, $\beta$ selinene, p-cymene, and $\alpha$-bisabolene [9].

The leaf extract of $O$. gratissimum has been used extensively in the traditional medicine system in many countries. The extracts from this plant have been used to treat high fever, cold, fungal infection, epilepsy, diarrhea [10], and cytotoxic activity against the human prostate adenocarcinoma cancer [11]. Though reports on the amber vial.
Published Online: November 21, 2020

ISSN: $2684-4478$

DOI : 10.24018/ejchem.2020.1.6.26

\section{A. Duru}

Department of Chemistry, Federal University of Technology, Nigeria.

(e-mail: iduru015@gmail.com) C. E. Duru*

Department of Chemistry, Imo State University, Nigeria. (e-mail: chidiedbertduru@ gmail.com)

*Corresponding Author

medicinal uses of $O$. gratissimum essential oil abound in literature, studies to identify the actual phytochemicals responsible for these observed activities are either scarce or unavailable. In this study, we identified the phytochemical components in the essential oil from $O$. gratissimum leaves. The activity of these compounds against PIM-1 protein of E. coli was investigated using in silico approach.

\section{Methodology}

\section{A. Collection of Plant Materials and Essential Oil Extraction}

Fresh Ocimum gratissimum leaves were plucked from a household garden in Owerri, Imo State, Nigeria. They were adequately washed with tap water, sliced into small pieces, and subjected to extraction by hydrodistillation, using a hot plate and Clevenger system as condenser and oil collector. $200 \mathrm{~g}$ of the chopped leaves were immersed in $500 \mathrm{~mL}$ distilled water in a $1 \mathrm{~L}$ flat bottom flask, and the extraction was carried out for $2 \mathrm{~h}$ at $100{ }^{\circ} \mathrm{C}$. The essential oil was collected, dried over anhydrous sodium sulphate, and filtered. The collected oil was stored at $-20^{\circ} \mathrm{C}$ in a glass

\section{B. Phytochemical Analysis of Essential Oil}

The phytochemicals in the essential oils were analyzed using a Buck 530 gas chromatograph equipped with an oncolumn, automatic injector, Electron capture detector, HP 88 capillary column $(100 \mathrm{~m} \times 0.25 \mu \mathrm{m}$ film thickness $) \mathrm{CA}$, USA. $100 \mathrm{mg}$ of oil was dissolved in $1.5 \mathrm{~mL}$ of dichloromethane, and 10 of this solution was injected into the GC-FID spectrometer. A RESTEK 15 m MXT-1 column 
$(15 \mathrm{~m} \times 250 \mu \mathrm{m} \times 0.15 \mu \mathrm{m})$ was used, and the injector temperature was kept at $280{ }^{\circ} \mathrm{C}$ with splitless injection of 2 $\mu \mathrm{L}$ of sample and a linear velocity of $30 \mathrm{cms}^{-1}$. Helium 5.0 Pa.s was the carrier gas with a flow rate of $40 \mathrm{~mL} / \mathrm{min}$. The oven was operated initially at $180{ }^{\circ} \mathrm{C}$ while the $\mathrm{GC}$ was allowed to warm up and then heated to $330{ }^{\circ} \mathrm{C}$ at a rate of $5^{\circ} \mathrm{C} / \mathrm{min}$ and kept at this temperature for $5 \mathrm{~min}$. The detector was operated at a temperature of $300{ }^{\circ} \mathrm{C}$. The ratio between the area and mass of internal standard and the area of the phytochemicals detected were used to identify the phytochemicals [12], [13].

\section{Identification and Preparation of Molecular Targets in PIM-1 Kinase Protein}

PIM-1 kinase of Escherichia coli (4JX7) was identified from literature and downloaded from the Protein Data Bank (PDB). PIM-1 kinase proteins have been implicated in both hematopoietic malignancies and solid cancers [14] and are, therefore, promising targets for cancer therapy. The target was prepared using UCSF Chimera 1.14.

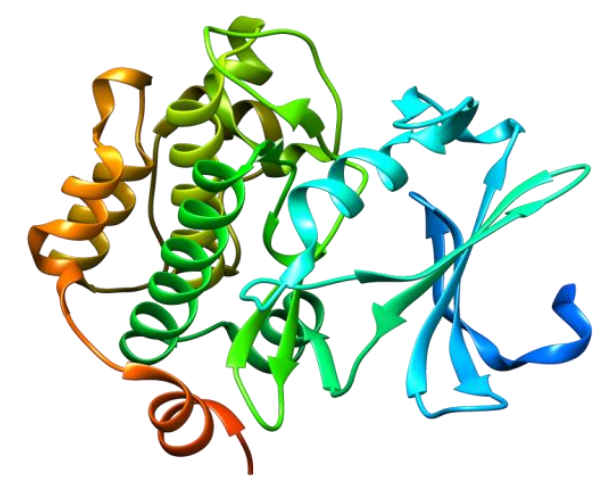

Fig. 1. PIM-1 kinase of Escherichia coli.

\section{Determination of Active Site on Protein}

The active sites of the protein were determined using The Computed Atlas for Surface Topography of Proteins (CASTp) [15].

\section{E. Docking Studies}

The screening of the phytochemical compounds in the oil was performed by site-directed docking on a specified PIM1 kinase protein binding pocket and ranked based on their dock scores. The multiple docking of the ligands and protein was done with Autodock Vina in PyRx software [16], and results in terms of binding energy were obtained. Apalutamide was used as the standard drug for the docking.

\section{F. Analysis of Protein-Ligand Interactions}

Hydrogen bonding and hydrophobic interactions between the protein-ligand complexes of the most potent compound and control drug was visualized using Biovia Discovery studio 4.5 [17] and UCSF Chimera software [18]

\section{G. Adsorption, Distribution, Metabolism, Elimination, and Toxicity (ADMET) Analysis}

The compound with the lowest binding energy on the protein was selected and submitted to the ADMETsar server to examine and compare its drug-like properties with the control drug [19].

\section{RESUlTS AND DisCUSSION}

The GC-FID chromatogram of phytochemical components in $O$. gratissimum essential oil is shown in Fig. 2 and their quantities shown in Table 1.

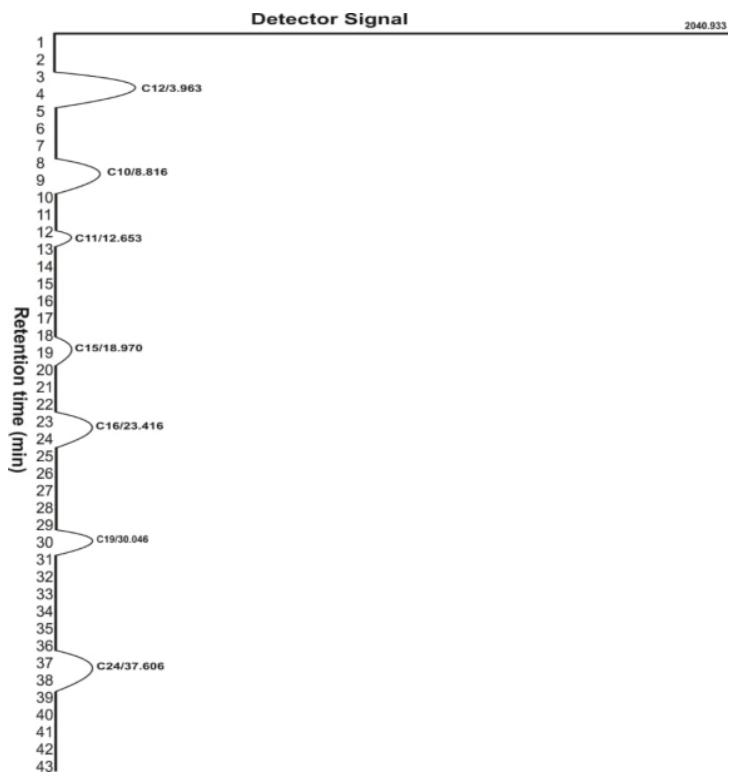

Fig. 2. GC chromatogram of essential oil components in O. gratissimum.

The identified compounds were in the order isobornyl acetate $(64.3 \%)>$ Octamethylhexadecan-1-ol $(12.2 \%)>$ nonadecanal $(11.5 \%)>$ decanal $(8.7 \%)>$ undecanal $(2.8 \%)$ $>\alpha$-Selinene $(0.5 \%)>$ drimenin $(<0.1 \%)$.

TABLE 1: QUANTITATIVE DESCRIPTION OF PHYTOCHEMICAL COMPONENTS

\begin{tabular}{cccc}
\multicolumn{4}{c}{ IN O. GRATISSIMUM } \\
\hline \hline S/N & Component & Elution time & $\begin{array}{c}\text { Concentration } \\
(\mu \mathrm{g} / \mathrm{L})\end{array}$ \\
\hline 1 & Isobornyl acetate & 3.96 & 510.31 \\
2 & Decanal & 8.82 & 68.88 \\
3 & Undecanal & 12.65 & 22.51 \\
4 & $\alpha-$ Selinene & 18.97 & 4.17 \\
5 & Drimenin & 23.42 & 0.13 \\
6 & Nonadecanal & 30.05 & 91.30 \\
7 & Octamethylhexadecan-1-ol & 37.61 & 96.76 \\
\hline \hline
\end{tabular}

The effects of PIM kinases on cancer cell motility have been extensively studied in prostate cancer, where they have been shown to increase migration, invasion, and adhesion of cultured cells in vivo [20]. The activity of the essential oil components against the PIM-1 kinase of E. coli was determined in silico using Apalutamide as the control drug. The binding affinities of the compounds to this target protein are shown in Table 2 . The binding affinity of $\alpha$ selinene $(-7.8 \mathrm{Kcal} / \mathrm{mol})$ was very close to the control drug $(-7.9 \mathrm{Kcal} / \mathrm{mol})$. These values indicated that this natural compound could have similar activity on PIM-1 kinase as the synthetic drug Apalutamide used as control. Essential oils that contain $\alpha$-selinene have been shown to have excellent activity against $E$. coli in many in vitro studies [21], [22]. 
TABLE 2: BINDING AFFINITIES OF THE PHYTOCHEMICAL COMPOUNDS FOR PIM1 KINASE OF E. COLI

\begin{tabular}{|c|c|c|}
\hline Component & Structure & $\begin{array}{l}\mathrm{G} \mathrm{Energy} \\
(\mathrm{Kcal} / \mathrm{mol})\end{array}$ \\
\hline $\begin{array}{c}\text { Isobornyl } \\
\text { acetate }\end{array}$ & & -5.9 \\
\hline Decanal & & -5.6 \\
\hline Undecanal & & -5.2 \\
\hline$\alpha$-Selinene & & -7.8 \\
\hline Drimenin & & -7.3 \\
\hline Nonadecanal & & -5.9 \\
\hline $\begin{array}{l}\text { Octamethylh } \\
\text { exadecan-1- } \\
\text { ol }\end{array}$ & & -6.4 \\
\hline $\begin{array}{l}\text { Apalutamide } \\
\text { (control) }\end{array}$ & & -7.9 \\
\hline
\end{tabular}

The 3D and 2D protein-ligand interaction images for $\alpha$ selinene and Apalutamide are shown in Fig. 3.

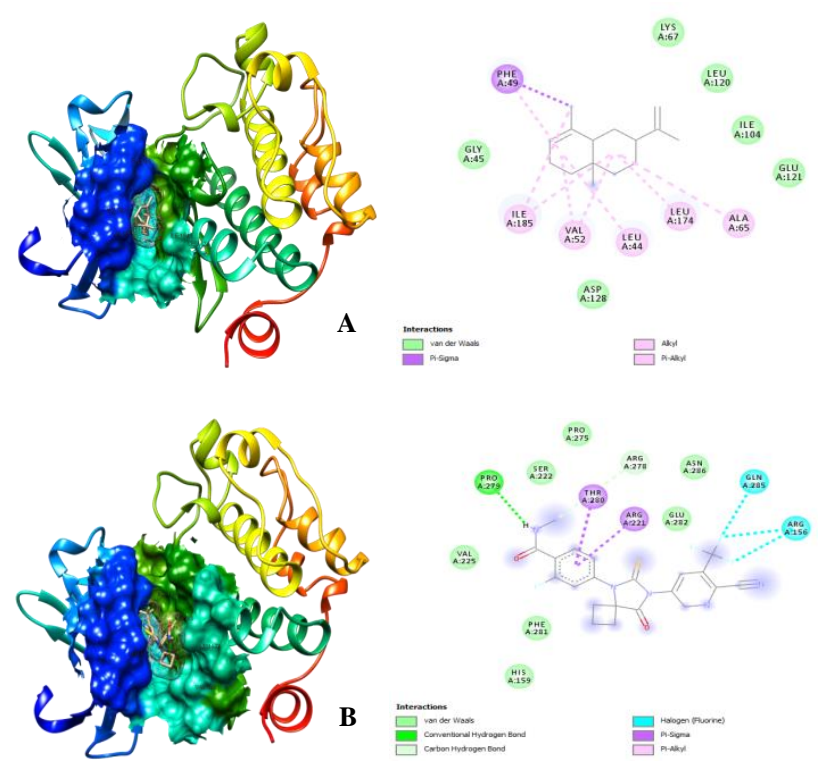

Fig. 3. 3D (left) and 2D (right) views of molecular interactions of (A) $\alpha$ selinene and (B) Apalutamide.
Alkyl and pi-sigma interactions were the forces holding the $\alpha$-selinene in the selected active site of the protein. In contrast, conventional hydrogen bonds, carbon-hydrogen bonds, and halogen interactions held the control drug at this active site. This observation is an indication that Apalutamide is more stable than $\alpha$-selinene at this pocket and, therefore, would bind more tenaciously and persist at this active site than $\alpha$-selinene.

The Absorption, Distribution, Metabolism, Excretion, and Toxicity (ADMET) properties of $\alpha$-selinene and Apalutamide, revealed their pharmacokinetics and pharmacodynamics properties, and are summarized in Table 3. The Lipinski's rule of five was used to suggest the drug likeliness of the compounds. A good drug candidate should not violate more than one of the rules [23].

\begin{tabular}{ccc} 
TABLE 3: ADMET PROPERTIES OF A-SELINENE AND APALUTAMIDE \\
\hline \hline ADMET Properties & $\alpha$-selinene & Apalutamide \\
\hline Molecular weight & 204.36 & 477.44 \\
logP & 4.73 & 3.53 \\
H-Bond Acceptor & 0 & 5 \\
H-Bond Donor & 0 & 1 \\
Rotatable Bonds & 1 & 3 \\
Acute Oral Toxicity & 3.05 & 3.93 \\
\hline \hline
\end{tabular}

The molecular weight of $\alpha$-selinene is $<500$, and its hydrophobicity $(\log \mathrm{P})$ did not exceed 5 . The hydrogen bond donor ( 5 hydrogen) and hydrogen bond acceptor (not more than 10 hydrogen) of the compound was in line with the rule. The rotatable bonds (not more than 3 ) followed the rule of three, and its acute oral toxicity was $<5 \mathrm{mg} / \mathrm{kg}$. These results indicated that $\alpha$-selinene is a better drug candidate than Apalutamide.

\section{CONCLuSions}

The composition and concentration of phytochemicals in the essential oil of Ocimum gratissimum were determined by GC-FID method. The identified phytochemical components were isobornyl acetate, octamethylhexadecan-1-ol, nonadecanal, decanal, undecanal, $\alpha$-Selinene, and drimenin. The in silico study of the activities of these compounds against PIM-1 kinase of Escherichia coli showed that $\alpha$ selinene had a very good affinity for this protein. The ADMET studies revealed that the compound is a promising drug candidate for PIM-1 kinase protein of E. coli. Therefore, regular consumption of this plant's leaf by middle-aged men and above as an anti-prostate supplement is suggested.

\section{ACKNOWLEDGMENT}

The authors are grateful to ChemSolvers Research and Computational Laboratory, Owerri, Nigeria, for their assistance in the in silico study. 


\section{REFERENCES}

[1] Mondal, S., Mahapatra, S., Naik, S., and Mirdha, B. (2007). Antimicrobial activities of essential oils obtained from fresh and dried leaves of Ocimum sanctum (L.) against enteric bacteria and yeast. Acta Horticulturae, 756:267-270.

[2] Khalid, K.A. (2006). Influence of water stress on growth, essential oil, and chemical composition of herbs (Ocimum sp.). International Agrophysics, 20(4):289-296.

[3] Effraim, K.D., Jacks, T.W. and Sodipo, O.A. (2003). Histopathological studies on the toxicity of Ocimum gratissimum leave extract on some organs of rabbit. African Journal of Biomedical Research, 6:21-25.

[4] Nwauzoma, A.B. and Dappa, M.S. (2013). Ethnobotanical studies of Port Harcourt Metropolis, Nigeria. ISRN Botany, Article ID 829424, 11 pages http://dx.doi.org/10.1155/2013/829424.

[5] Sartoratto, A., Machado, A.L.M., Delarmelina, C., Figueira, G.M., Duarte, M.C.T. and Rehder, V.L.G. (2004). Composition and antimicrobial activity of essential oils from aromatic plants used in Brazil. Brazilian Journal of Microbiology. 2004, 35(4):275-80.

[6] Zoghbi, M.G.B., Oliveira, J., Andrade, E.H.A., Trigo, J.R., Fonseca, R.C.M. and Rocha, A.E.S. (2007). Variation in volatiles of Ocimum campechianum Mill. and Ocimum gratissimum L. cultivated in the North of Brazil. Journal of Essential Oil Bearing Plants, 10(3):229240 .

[7] Iriti, M. and Faoro, F. (2009). Chemical diversity and defense metabolism: How plants cope with pathogens and ozone pollution. International Journal of Molecular Sciences, 10:3371-3399.

[8] Suhr, K.I. and Nielsen, P.V. (2003). Antifungal activity of essential oils evaluated by two different application techniques against rye bread spoilage fungi. Journal of Applied Microbiology, 94(4):665674.

[9] Vieira, R.F., Grayer, R.J., Paton, A. and Simon, J.E. (2001). Genetic diversity of Ocimum gratissimum L. based on volatile oil constituents, flavonoids and RAPD markers. Biochemical Systematics and Ecology, 29(3):287-304.

[10] Ijeh, I.I., Omodamiro, O.D. and Nwanna, I.J. (2005). Antimicrobial effects of aqueous and ethanolic fractions of two spices, Ocimum gratissimum and Xylopia aethiopica. African Journal of Biotechnology, 4:953-956.

[11] Njoku, C.J., Zeng, L., Asuzu, I.U., Oberlies, N.H. and Mclaughlin, J.L. (1997). Oleanolic acid, a bioactive component of the leaves of Ocimum gratissimum (lamiaceae). International Journal of Pharmacognosy, 35:134-137.

[12] Duru, I.A. and Duru, C.E. (2019). Identification and quantification of phytochemicals from Carica papaya Linn (Caricaceae) root extract using GC-FID. Journal of Chemical Society of Nigeria, 44(7):12911297.

[13] Duru, C.E. (2020). Mineral and phytochemical evaluation of Zea mays husk. Scientific African, 7: e00224.

[14] Santio, N.M., Salmela, M., Arola, H., Eerola, S.K., Heino, J., Rainio, E.M. and Kaskinen, P.J. (2016). The PIM1 kinase promotes prostate cancer cell migration and adhesion via multiple signaling pathways. Experimental Cell Research, 342(2):113-124.

[15] http://sts.bioe.uic.edu/castp/index.html?j_5f45dd381f58d.

[16] Tsao, Y.C., Chang, Y.J., Wang, C.H. and Chen, L. (2020). Discovery of isoplumbagin as a Novel NQO1 substrate and anti-cancer Quinone. International Journal of Molecular Sciences, 21(12):4378.

[17] BIOVIA, D.S. (2015). Discovery studio modeling environment. San Diego, Dassault Systemes, Release, 4

[18] Pettersen, E.F., Goddard, T.D., Huang, C.C., Couch, G.S., Greenblatt, D.M., Meng, E.C., and Ferrin, T.E. (2004). UCSF Chimera- a visualization system for exploratory research and analysis Journal of Computational Chemistry, 25(13):1605-1612.

[19] Yang, H., Lou, C., Sun, L., Li, J., Cai, Y., Wang, Z., Li, W., Liu, G. and Tang, Y. (2019). admetSAR 2.0: Wed-service for prediction and optimization of chemical ADMET properties. Bioinformatics (Oxford, England), 35(6):1067-1069.

[20] Santio, N.M. and Koskinen, P.J. (2017). PIM kinases: from survival factors to regulators of cell motility. The International Journal of Biochemistry and Cell Biology, 93:74-85.

[21] Wang, X., Shen, Y., Thakur, K., Han, J., Zhang, J.G., Hu, F. and Wei, Z.J. (2020). Antibacterial activity and mechanism of ginger essential oil against Escherichia coli and Staphylococcus aureus. Molecules, 25:3955.

[22] Berthold-Pluta, A., Stasiak-Różańska, L., Pluta, A. and Garbowska, A. (2019). Antibacterial activities of plant-derived compounds and essential oils against Cronobacter strains. European Food Research and Technology, 245:1137-1147.
[23] Lipinski, C.A. (2016). A rule of five in 2015 and beyond. Target and ligand structural limitations, ligand chemistry structure and drug discovery project decisions. Advanced Drug Delivery Reviews, 101:34-41. 